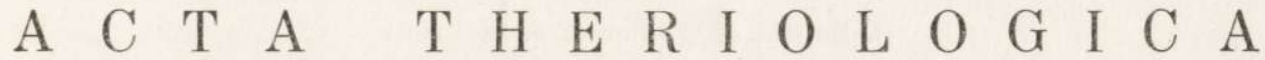

VOL. XVII, 15: 187-202.

BIA£OWIEŻA

August, 1972

Bogusław B O B E, January W E I N E R \& Jan Z I E L I Ń S K I

\section{Food Supply and its Consumption by Deer in a Decidous Forest of Southern Poland*}

\author{
|With 6 Tables \& 2 Figs.]
}

The food resources for deer in deciduous forests of Tilio-Carpinetum type in Southern Poland and their utilization by Capreolus capreolus and Cervus elaphus have been estimated. The clipping was carried out in summer, autumn, winter and early spring, on 21 fenced and 21 unfenced plots, $5 \times 10 \mathrm{~m}$ each. The forage was found to be the highest in summer $\left(567.0 \mathrm{kcal} / \mathrm{m}^{2}\right)$ and the lowest in winter $\left(125.9 \mathrm{kcal} / \mathrm{m}^{2}\right)$. In the latter case it consisted of twigs of the oak, Quercus robur - $75.8 \%$, hornbeam, Carpinus betulus - $18.4 \%$, small-leaved lime, Tilia cordata $-3.1 \%$, and other species $(2.6 \%)$. The annual production of the food available for deer in the plantations of different age amounts on the average to $587.1 \mathrm{kcal} / \mathrm{m}^{2}$. The consumption by deer was estimated on the basis of the number of browsed twigs, as well as from the difference in the browse supply on the fenced and unfenced plots. During the whole year deer consume in the plantations $49.1 \mathrm{kcal} / \mathrm{m}^{2}$ (including $29.6 \mathrm{kcal}$ from April to October and $19.5 \mathrm{kcal}$ from November till March). Hence the consumption constitutes $8.4 \%$ of the food available during the whole year, while this figure in winter reaches $15.7 \%$. Young plantations are the most exposed to damage, and there $26 \%$ of twigs are browsed.

The food preference of deer was estimated by the precentage of utilization of the browse from different trees and shrubs in winter. In deciduous plantations of various age the most attractive species are: poplar, Populus tremula, alder buckthorn, Frangula alnus, willow, Salix caprea. The employment of food preference in order to reduce damage to plantations is discussed.

\section{INTRODUCTION}

The basic food for deer consists of browse, and to a smaller extent of grasses and herbs (Siuda, Żurowski \& Siuda, 1969; Dzięciolowski, 1970a). The browse includes the current growth of twigs of trees and shrubs remaining within the reach of the animals (Dzi e--

- This study was carried out under the Project No. 09.1.7. co-ordinated by the Institute of Ecology Polish Academy of Sciences. 
ci o łow ski, 1969; Y oak um \& D a smann, 1969). The food carryirgs capacity of a habitat depends on the abundance of such foods, hence in many countries the attempts of its estimation have been undertaken. The first studies on this subject were carried out on the continent of North-America (Shafer, 1963; Hadley \& Bliss, 1964; Schruster. 1965; $\mathrm{H}$ a $1 \mathrm{ls} \& \mathrm{D}$ e $1 \mathrm{l}, 1966)$. In the European countries the investigations on this line were accomplished in Poland ( $\mathrm{Dzi}$ ęciołowski, 1969) and Soviet Union ( $\mathrm{Pad}$ a i g a, 1970), and fairly similar also in Czechoslovakia (V a n e k, 1958).

The browse is distributed not evenly in the forest. It is the most abundant in timber stand. In insolated areas such as plantations the browse provides more mineral compounds and easily digestible parts ( $\mathrm{H}$ a $11 \mathrm{~s}$ \& E p p s, 1969). This results in the concentration of animals in the plantations and in effect in the occurrence significant damages there. The reduction of these damages is not possible without accurate estimation of food resources of deer, and without knowledge of their food habits.

The present study is concerned with the estimation of food supply and utilization by deer in the plantations of the deciduous forest of Tilio-Carpinetum type. Moreover, an attempt was undertaken to establish the species of trees and shrubs highly preferred by these animals.

\section{AREA OF THE INVESTIGATIONS, MATERIAL AND METHODS}

The Niepolomicka Primeval Forest is situated in the Vistula Valley to the East of Kraków $\left(50^{\circ} 07^{\prime} \mathrm{N}, 20^{\circ} 23^{\prime} \mathrm{E}\right)$ and covers the area of approximately 11 thousands ha. It consists mainly of pine forests, and to a smaller extent of rich deciduous forests of Tilio-Carpinetum type. From among large herbivorous mamals the roe deer, $\mathrm{Ca}$ preolus capreolus (Linnae us, 1758) and red deer, Cervus elaphus Linna e us, 1758 occur there. The studies on the food supply for deer in forest plantations were carried out in the northern part of the Niepolomicka Forest within the complex of deciduous forestes of Tilio-Carpinetum type (Forest Inspectorate Damienice). There are present mainly oak, Quercus robur plantations with a small admixture of hornbeam, Carpinus betulus, small-leaved lime, Tilia cordata, poplar, Populus tremula, willow, Salix caprea and white birch, Betula sp. Among shrubs decidedly dominate blackberry, Rubus sp., while others, such as alder buckthorn, Frangula alnus, whitehorn, Crategus oxyacantha and elder, Sambucus nigra, constitute a small per cent only.

The plot method was employed in connection with clipping. The investigations were made in a full year cycle from the spring 1970 to the spring 1971. In April twenty one square plots $10 \times 10 \mathrm{~m}$ were delineated. Each of them was divided into two halves, one of them being surrounded by a $2 \mathrm{~m}$ high wire fence. In this way 42 rectangle plots $(10 \times 5 \mathrm{~m})$ were obtained, and 21 of them were secured from browsing of red and roe deer. The plots were situated in three different stages of the plantation age: young plantation (around 3 years old), middle-age plantation (5-6 years) and old plantation (around 9 years old). Then in summer, autumn, 
winter and early spring the browse, as well as grasses and herbs, were clipped on consecutive fenced and unfenced plots. In such way in July the material was collected from six plots, and in October, February and April from the consecutive 12 plots each time. The browse was collected separately from each tree, then it was weighed, dried to a constant weight and combusted in a calorimetric bomb (G órecki, 1965; Lieth, 1968). Grasses and herbs were clipped just above the ground and then their fresh weight, dry weight and caloric value were determined. When cutting the browse the number of browsed twigs on each tree was estimated and the twig diameter was determined with a vernier calipers. In the last two collections (February and March-April) also the tree diameter was determined at the root neck ( $\mathrm{T}$ elf e r, 1969a) in order to establish a relation between the mass of browse and tree age. To estimate the mean weight of the consumed browse samples of control twigs were also collested. They were air-dried, cut at the section determined by the average diameter of point of browsing $(d b p)$ (Shafer, 1963; T e lf e r, 1969b) and accurately weighed.

The total consumption by deer was finally estimated by the two methods: (1) from the difference in the supply of browse on fenced and unfenced plots, and (2) from the number of browsed twigs.

\section{RESULTS}

\section{Seasonal Changes in the Food Supply for Deer}

The food resources in the form of browse depend mainly on the plantation age. Independently of the season the browse is the most abundant in an old plantation and the least - in a young one (Table 1). On the

Table 1

Seasonal changes of the browse supply in the plantations of different age in deciduous forest of Tilio-Carpinetum type. All values are given in $\mathrm{g}$ dry $\mathrm{wt} . / \mathrm{m}^{2}$.

\begin{tabular}{lrrrr}
\hline Plantation age & Summer & Autumn & Winter & Spring \\
& & & & \\
\hline 3 years & 21.1 & 16.0 & 8.0 & 9.5 \\
6 years & 70.1 & 40.3 & 22.5 & 28.8 \\
9 years & 205.4 & 102.0 & 51.3 & 53.3 \\
Mean & 98.9 & 52.8 & 27.3 & 30.5 \\
\hline
\end{tabular}

average for all plantations the largest supply of browse was recorded in summer when it reached as much as $98.9 \mathrm{~g}$ dry wt. $/ \mathrm{m}^{2}$. This value consists mainly of the biomass of leaves, of which the highest percentage was recorded in oak $(77.5 \%)$ and the smallest in blackberry $(47.5 \%)$. The current growth of twigs alone amount to $24.3 \mathrm{~g}$ dry wt. $/ \mathrm{m}^{2}$. In autumn due to a partial fall of leaves (October) the food supply of browse became reduced to $52.8 \mathrm{~g}$ dry wt. $/ \mathrm{m}^{2}$. A drastic reduction in the supply of 
browse was noted in winter. The lack of leaves and disappearance of stems of blackberry bushes under snow causes that roe and red deer have at their disposal only $27.3 \mathrm{~g}$ dry $\mathrm{wt} . / \mathrm{m}^{2}$. On the last of March and beginning of April a slightly higher supply of browse is noted: 30.5 dry wt. $/ \mathrm{m}^{2}$ (Table 1$)$.

In summer the highest share in the forage of browse is from oak $(70.1 \%)$, and in further order for blackberry $(16.6 \%)$ and hornbearn $(9.1 \%)$. The remaining part consists of small-leaved lime $(2.3 \%)$ and poplar, willow, white birch, elder and whitehorn (jointly $2.1 \%$ ) (Fig. 1). In winter these values undergo certain modifications: blackberry bush disapears, oak constitutes $75.8 \%$, hornbeam $18.4 \%$ and lime $3.1 \%$. Other species reach jointly $2.6 \%$ share in the total supply of browse.

The biomass of grasses and herbs, in contrast to the browse, decreases with the plantation age. This fact is related to a considerable canopy in

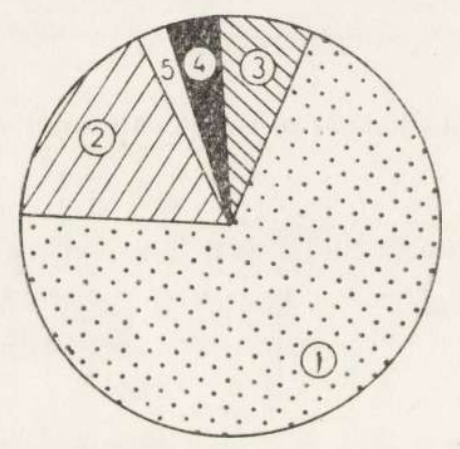

Fig. 1. Mean proportion of individual tree and shrub species in the supply of browse in deciduous plantations of different age. $1-$ oak. $2-$ blackberry, 3 - hornbeam, 4 - lime, 5 - others.

older trees ( $\mathrm{H}$ a 11 \& D e 11,1965$)$. In summer the young plantation contains $35.5 \mathrm{~g}$ dry wt. $/ \mathrm{m}^{2}$ of herbs and grasses, middle-age plantation $18.3 \mathrm{~g}$ dry wt. $/ \mathrm{m}^{2}$, and old plantation only $16.8 \mathrm{~g}$ dry wt. $/ \mathrm{m}^{2}$. This gives the average value of $22.9 \mathrm{~g}$ dry wt. $/ \mathrm{m}^{2}$. In autumn for $1 \mathrm{~m}^{2}$ falls on the average $29.6 \mathrm{~g}$ dry wt.; this value includes both young plantations (43.5 g dry wt. $\left./ \mathrm{m}^{2}\right)$, middle-age plantations $\left(23.6 \mathrm{~g}\right.$ dry $\left.\mathrm{wt} . / \mathrm{m}^{2}\right)$ and old plantations $\left(21.6 \mathrm{~g}\right.$ dry wt. $\left./ \mathrm{m}^{2}\right)$. The lowest biomass of grasses and herbs was noted in early spring: $0.2 \mathrm{~g}$ dry wt. $/ \mathrm{m}^{2}$ on the average for all plantations.

Table 2 gives caloric values of twigs and leaves of selected species of trees and shrubs, as well as the mean value for a joint sample of grasses and herbs. The data are fairly similar and all remain within the range of 4.390 (leaves of elder) and $4.904 \mathrm{kcal} / \mathrm{g}$ dry wt. (leaves of willow). The caloric value of leaves is always higher than that of stems in elder. The 
highest value of stems was shown by poplar, while the lowest - by elder. Among leaves the highest value have those of willow and the lowest of elder. Relatively low caloric value was found for grasses and herbs: $4.550 \mathrm{kcal} / \mathrm{g}$ dry wt.

The estimation of caloric value of food for deer allowed to express in $\mathrm{kcal} / \mathrm{m}^{2}$ the food supply for these animals in different seasons (Table 3). The smallest food resources were found in young plantations in winter (only $36.9 \mathrm{kcal} / \mathrm{m}^{2}$ ), and the highest in old plantations in summer $(1040.0$

Table 2

Caloric values (in $\mathrm{kcal} / \mathrm{g}$ dry wt.) of stem and leaves of some trees and shrubs as well as grasses and herbs. All samples were collected in summer.

\begin{tabular}{lcc}
\hline \multicolumn{1}{c}{ Species } & Stems & Leaves \\
\hline Quercus robur & 4.621 & 4.732 \\
Carpinus betulus & 4.722 & 4.801 \\
Tilia cordata & 4.641 & 4.871 \\
Populus tremula & 4.818 & 4.895 \\
Salix caprea & 4.589 & 4.904 \\
Sambucus nigra & 4.538 & 4.390 \\
Rubus sp. & 4.567 & 4.647 \\
Frangula alnus & 4.701 & 4.809 \\
Grasses + herbs & - & 4.550 \\
\hline
\end{tabular}

Table 3

Supply of food available for deer (browse and herb layer plants) in consecutive seasons in deciduous plantations of different age (all values computed for $\mathrm{kcal} / \mathrm{m}^{2}$ ).

\begin{tabular}{lrrrr}
\hline Plantation age & Summer & Autumn & Winter & Spring \\
& & & & \\
\hline 3 years & 251.3 & 272.1 & 36.9 & 47.4 \\
6 years & 410.9 & 291.4 & 103.9 & 132.9 \\
9 years & 1040.0 & 537.4 & 236.8 & 246.7 \\
Mean & 567.4 & 379.0 & 125.9 & 142.3 \\
\hline
\end{tabular}

$\mathrm{kcal} / \mathrm{m}^{2}$ ). On the average, the plantations in any age have the highest food supply in summer (mean $567 \mathrm{kcal} / \mathrm{m}^{2}$ ) and slightly smaller in autumn $\left(379 \mathrm{kcal} / \mathrm{m}^{2}\right)$. A considerable reduction in the amount of food available occurs in winter, and is accompanied also by a change in its composition. Leaves, grasses and herbs, as well as stems of blackberry bushes are lacking. For this reason food supply is reduced to some stems only and amounts to $125.9 \mathrm{kcal} / \mathrm{m}^{2}$, or 4.5 times less than in summer. In 
spring $142.3 \mathrm{kcal}$ falls for $1 \mathrm{~m}^{2}$ on the average. This value includes stems and small amounts of grasses and herbs which begin growth.

\section{Browsing}

Table 4 shows the dynamics of consumption of the browse in relation to the plantation age and the season. The obtained results indicate an abrupt increase in the exploitation of the plantations in winter and autumn. The mean number of browsed twigs for $1 \mathrm{~m}^{2}$ amounted in July to 1.7 only, but it increased to 6.1 in autumn, 15.7 in winter and 25.7 in early spring. The highest rise in the number of browsed twigs was noted in young plantations: 8 times from summer till autumn and 3 times from autumn till winter. Then the rate of utilization decreased in young plantations and rised in middle-age and old plantations. The increase in the

Table 4

Number of browsed stems on deciduous plantations as estimated in different seasons. Numbers correspond to actual browsed twigs per $1 \mathrm{~m}^{2}$ of plantation, and they increase in spring. In parentheses number of stems browsed between two consecutive seasons is given.

\begin{tabular}{lclll}
\hline Plantation age & Summer & Autumn & Winter & Spring \\
\hline 3 years & $0.7(0.7)$ & $4.7(4.0)$ & $14.2(9.5)$ & $17.6(3.4)$ \\
6 years & $1.2(1.2)$ & $5.2(4.0)$ & $11.0(5.8)$ & $27.6(16.6)$ \\
9 years & $3.1(3.1)$ & $8.4(5.3)$ & $21.8(13.4)$ & $32.0(10.2)$ \\
Mean & $1.7(1.7)$ & $6.1(4.4)$ & $15.7(9.6)$ & $25.7(10.0)$ \\
\hline
\end{tabular}

number of browsed twigs in old plantations is not so great but it should be remembered that in winter the mean diameter and weight of the consumed twig is higher there (Table 5).

The percentage distribution of browsed twigs estimated in spring is not proportional to the total food supply and this indicates the existence of a marked food preference in deer. The highest proportion in the consumed twigs fells for oak $(79.8 \%)$ and hornbeam $(13.9 \%)$. Then there were lime $2.4 \%$, alder buckthorn $1.5 \%$, poplar $1.3 \%$ an willow $0.9 \%$. Birch, whitehorn and elder constituted jointly $0.2 \%$.

The mean diameter of twigs in the point of browsing $(d p b)$ was estimated for all species of trees and shrubs (Table 5). In this table also the mean weight of the browsed twigs (in g dry wt.) is given. This was estimated by weighing of air-dried twigs that had been randomly selected and cut in the point corresponding to the mean $d p b$. 
The $d p b$ of oak twigs changes in relation to the season and plantation age. Until autumn it amounts on the average to $1.8 \mathrm{~mm}$ and is the same in plantations of different age. In winter these diameters increase to $2 \mathrm{~mm}$ in young and middle-age plantation, and to $2.6 \mathrm{~mm}$ in old plantation;. In other plant species no such relationship was found to exist between the $d p b$ and the plantation age or season. Among all trees and shrubs the oak shows the largest $d p b$, while the hornbeam - the smallest one (Table 5). The highest variability in the period of vegetation was found for the diameter of browsed oak twigs $(C . V .=41.1 \%)$, and the smallest variability in alder buckthorn $(18.7 \%$, Table 5$)$.

The second part of Table 5 contains the weight of browsed twigs. A high weight of oak twigs in the full vegetation period is striking $(0.765 \mathrm{~g})$

Table 5

Mean diameters of browsed stems $(d b p)$ in $\mathrm{mm}$ and their weights in $\mathrm{g}$ dry wt.

\begin{tabular}{|c|c|c|c|c|}
\hline \multirow[t]{2}{*}{$\begin{array}{l}\text { Tree and shrub } \\
\text { species }\end{array}$} & \multicolumn{2}{|c|}{$d p b(\mathrm{~mm})$} & \multicolumn{2}{|c|}{$\begin{array}{l}\text { Weight of sbrowsed" stem } \\
\text { (g dry wt.) }\end{array}$} \\
\hline & $\overline{\mathrm{X}} \pm \mathrm{SD}$ & $\mathrm{CV}(\%)$ & $\overline{\mathrm{X}} \pm \mathrm{SD}$ & $\mathrm{CV}(\%)$ \\
\hline Q. robur 1 & $1.8 \pm 0.74$ & 41.1 & $0.765 \pm 0.310$ & 40.5 \\
\hline Q. robur ${ }^{2}$ & $2.0 \pm 0.47$ & 23.5 & $0.133 \pm 0.057$ & 42.8 \\
\hline Q. robur $^{3}$ & $2.6 \pm 0.85$ & 32.6 & $0.270 \pm 0.111$ & 41.1 \\
\hline C. betulus & $1.3 \pm 0.44$ & 33.8 & $0.082 \pm 0.033$ & 40.2 \\
\hline T. cordata & $1.5 \pm 0.46$ & 30.7 & $0.087 \pm 0.037$ & 42.5 \\
\hline S. caprea & $1.8 \pm 0.46$ & 25.5 & $0.133 \pm 0.059$ & 44.4 \\
\hline P. tremula & $1.7 \pm 0.39$ & 23.5 & $0.170 \pm 0.056$ & 32.9 \\
\hline F. alnus & $1.6 \pm 0.30$ & 18.7 & $0.092 \pm 0.036$ & 39.1 \\
\hline
\end{tabular}

${ }^{1}$ In the growing season. ${ }^{2}$ In winter in the plantations 3 and 6 years old. ${ }^{3}$ In winter in 9 year old plantation.

However, the leaves constitute a major part of this value, and the stem itself has only $0.122 \mathrm{~g}$. The weights of the remaining twigs devoid of leaves show small differences. The lightest are the twigs of hornbeam and lime, the heaviest - those of oak browsed in winter in old plantations. The coefficient of variability of browsed twigs is rather high, but similar in all species of trees and shrubs. In most cases it oscillates around $40 \%$.

The weight of the browsed twig has been estimated from the experimental weights of stems (Table 5) and the percentage share of indyvidual species. It corresponds to a "statistical twig «, based on the weighted mean for all species of trees and shrubs. For the winter period the weights of browsed twigs were multiplied by the percentage share of individuai species in the browsed food, and the obtained results were added up. Such a "mean twig " browsed in winter has been estimated as equal to $0.124 \mathrm{~g}$ in a young or middle-age plantation, and $0.252 \mathrm{~g}$ in an old plantation. 
Similar calculations were made for the summer period. The weight of the oak twig with leaves was multiplied by the percentage share of this species in the browsed food. No data were available for the stems of other species with leaves in the period of vegetation. For this reason the calculations were based on the weight of twigs without leaves (Table 5). adding the mean weight of leaves, which constitute approximately $85 \%$ of the total browsed twig. The weight of the "mean twig " (oak and other species) estimated in such way reaches in the period of vegetation as much as $0.713 \mathrm{~g}$.

\section{Effect of Fencing}

The effect of fencing was investigated with the use of small oak trees, because this species dominates in the plantations. The whole material of oaks was divided into age classes assuming as the criterion the stern diameter at the ground line; $5 \mathrm{~mm}$ intervals corresponded to age classes. A rather small class I $(0-5 \mathrm{~mm})$ was added to the second class $(6-$ $10 \mathrm{~mm}$ ), and the same was made with the oldest class VIII adding it to class VII (Table 6). At the beginning of this table there are listed the mean weights of the browse in g dry wt. (cf. column 2) falling for further order is given the weight of the browse falling for one tree from unfensed plots clipped in winter (February - column 3) and early spring (the turn of March and beginning of April). Moreover, the mean number of browsed twigs falling for one tree in each age class from winter to early spring was calculated.

It can be seen that the supply of browse increases with the tree age (Table 6). In the class I-II (data from fenced plots) the average value of browse supply is $5.83 \mathrm{~g}$ dry wt. per one tree, in class $\mathrm{V}-37.1 \mathrm{~g}$ dry wt., and class VII+VIII as much as $152.5 \mathrm{~g}$ dry wt. In comparison with this the amount of browse which was found by the end of March on unfenced plots is considerably smaller and amounts, respectively, to: $4.22,31.52,134.6 \mathrm{~g}$ dry wt./tree. Amounts of browse on fenced and unfenced plots differs significantly $(P<0.05)$ in all tree-age classes except the oldest one. The highest differences, amounting to $27.4^{0} \%$, were noted in the case of young trees. In the middle classes (III-V) the differences in the browse supply between fenced and unfenced plots amount to nearly $18.0 \%$, while in the oldest classes (VI-VII) - to barely $12.7 \%$.

The blackberry bush is the preferred food for the game in the vegetation period. The animals consume almost exclusively the leaves while the stems remain untouched. For this reason the differences in the supply of blackberry leaves on fenced and unfenced plots are considerable and 


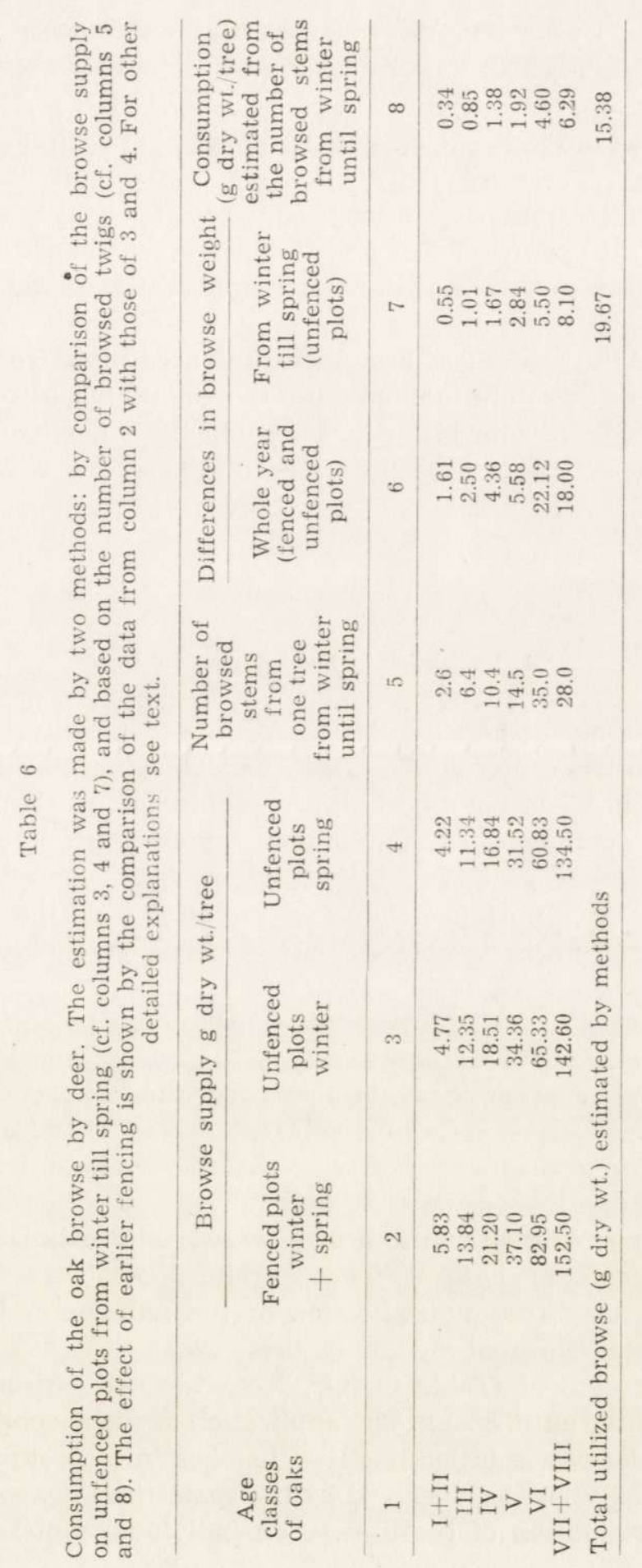


reach 0.64 dry wt. $/ \mathrm{m}^{2}$. On the other hand, no difference was found in the supply of grasses and herbs in fenced and unfenced plots.

For comparison, the consumption of the oak browse was also estimated by the method of Shafer (1963). Such estimation depends on the multiplication of browsed twigs by the mean weight of such a twig, as determined by random clipping. The results of this estimation are listed in the last column of Table 6 . It can be seen that in all age classes the consumption calculated from the number and weight of indivicual browsed twigs is lower than the consumption determined by the direct comparison of the amount of browse on unfenced plots from winter unti? spring. This last absolute method gave the estimation of consumption as $19.7 \mathrm{~g}$ dry wt., jointly for all age classes. On the other hand, the method based on browsed twigs gave the value of $15.4 \mathrm{~g}$ dry wt., i.e. lower by $28 \%$ (Table 6 ).

\section{DISCUSSION}

\section{Utilization of Food Supply by Deer}

The food supply of herbs and grasses showed no differences between fenced and unfenced plots. This fact indicates that in the plantations the deer do not consume herb layer plants to any significant degree. In this layer dominate grasses, among which Deschampsia coespitosa constitutes a great part. The selectivity of grass consumption by red deer (D zi ęciołowski, 1970a) and roe deer (Si uda, Żurowski \& Siuda, 1969) is very low, but it is known that Deschampsia coespitosa is avoided by roe deer (Klötzli, 1965).

The differences in the estimation of consumption by the two described methods arise probably from the fact that deer consume selectively the browse. They seem to avoid light and short stems. On the other hand such stems were certainly collected during random clipping. For this reason the collected twigs were on the average lighter by $28 \%$ from the twigs really consumed by deer.

The total consumption of the browse was finally estimated by employ-. ing the elements of both methods. From Shafer's method only the principle was used, i.e. multiplication of the number of browsed twigs by their weight. The real weight of these twigs was, however, obtained by the direct method (Table 6), i.e., from the comparison of unfenced plots from winter until spring. The application of such »combined " method seems to be the best solution, because it takes into account the selective consumption of stems by deer and at the same time it avoids errors due to uneven distribution of the browse on individual plots. The described 
procedure was possible for all trees and shrubs except blackberries, for which the indirect method was employed.

During seven months of the vegetation period (April-October) the food intake by deer was estimated as $29.6 \mathrm{kcal} / \mathrm{m}^{2}$. This mean value for plantations of different age consists mainly of leaves $\left(25.8 \mathrm{kcal} / \mathrm{m}^{2}\right)$ and to a much smaller extent of stems $(12 \%)$. In winter, i.e. from November till the end of March ( 5 months) food consumption amounted to 19.5 $\mathrm{kcal} / \mathrm{m}^{2}$. The winter food is much less valuable in respect of digestibility than the summer one ( $\mathrm{K} \mathrm{u} \mathrm{bota}$, Riegers \& L a zar, 1970). Jointly in the whole year deer consume $49.1 \mathrm{kcal}$ from each $\mathrm{m}^{2}$ of plantation.

The total primary production of the herb layer plants as well as stems and leaves of trees and shrubs has been determined from the standing crop during the growing season. Such production reached in various plantations $640.1 \mathrm{kcal} / \mathrm{m}^{2}$ year on the average. This value includes both grasses and herbs $(134.7 \mathrm{kcal})$, stems of trees and shrubs (150.9 $\mathrm{kcal})$, as well as their leaves ( $354.5 \mathrm{kcal})$. When the stems of blackberries are neglected $(53.0 \mathrm{kcal})$ then the annual production of the food available for deer will amount to $587.1 \mathrm{kcal} / \mathrm{m}^{2}$ year on the average. Consumption constitutes $8.4 \%$ of the food available during the year.

The capacity of a habitat for deer depends mainly on food resources. In the period from November until March the investigated plantations offer for roe deer the mean supply of available food in the amount of $124 \mathrm{kcal} / \mathrm{m}^{2}$. This value is already corrected by the number of twigs consumed in the growing season. In winter deer consume $19.5 \mathrm{kcal} / \mathrm{m}^{2}$, which constitutes $15.7 \%$ of their supply of food available in plantations. The food available is defined here as the current growth and includes also thicker stems which are inedible for the animals. For this reason a more accurate estimation of the winter food supply should be based on the stems cut at the place of their mean diameter of browsing.

The utilization of the food available during winter was different in plantations of various age. In relation to food supply the most utilized were young plantations where consumption by deer reached $26.1 \%$ of the food available (consumption $=9.6 \mathrm{kcal}$, supply $=36.4 \mathrm{kcal} / \mathrm{m}^{2}$ ). The utilization of food available was the lowest in old plantations where at a very high supply $\left(233.9 \mathrm{kcal} / \mathrm{m}^{2}\right)$ the consumption $\left(52.5 \mathrm{kcal} / \mathrm{m}^{2}\right)$ reached only. $13.9 \%$.

In the studied complex of deciduous forests ( 1800 ha) the numbers of deer was estimated two times in the year (spring and autumn) by using the driving census. In 1970/71 12 roe deer and 1.5 red deer fell there for 100 ha of the forest on the average (Bobek \& Tomek, unpubl. data). In respect of food requirements this number corresponds to approximately 18 roe deer ( $\mathrm{Pas}$ a a ski, 1969). The daily con- 
sumption of adult roe deer can be estimated as $2500 \mathrm{kcal} / \mathrm{animal}$ (Drożdż \& Osiecki, unpubl. data). The annual consumption of this population of deer reaches approximately $16.2 \mathrm{ml} \mathrm{kcal} \mathrm{from} \mathrm{each}$ 100 ha of the forest. This means that in respect of area the consumption by deer is three times higher in plantations than in the remaining parts of the forest.

Quantitative estimation of the plant food destroyed by deer, and the effect of browsing of these animal on the growth of small trees, are more difficult to be carried out. In some cases the amount of destroyed plant food may exceed that consumed by large mammals (T u r č e k, 1969). Certainly deer exert an unfavourable effect on the growth of small trees by destroying growing sprouts (Ahlén, 1965; Dinnes$\mathrm{m}$ a $\mathrm{n}, 1967)$.

\section{Food Preference of Deer}

The percentage of browse utilization during winter has been assumed as the index of food preference of roe and red deer in respect of various tree and shrub species (Fig. 2). In the youngest plantations, which were

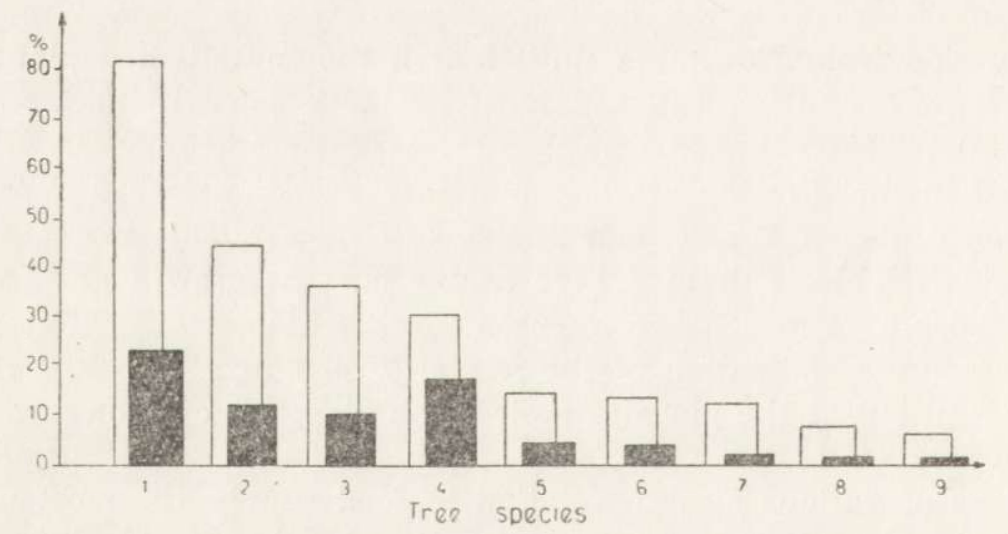

Fig. 2. Food preference of deer in relation to different trees and shrubs during winter. The height of bars corresponds to the percentage of utilization of browse supply among individual species in young plantations (open bars) and old plantations (full bars). 1 - poplar, 2 - willow, 3 - alder buckthorn, 4 - oak, 5 - lime, 6 - hornbeam, 7 - birch, 8 - whitehorn, 9 - elder.

the most imperilled by deer, the following species were willingly consumed (in the decreasing order): poplar, willow, alder buckthorn and oak. The poplar was certainly the most attractive and its winter browse supply was utilized in as much as $81.0 \%$ ! The willow browse was consumed by deer in $44.1 \%$, alder buckthorn in $36.3 \%$ and oak in $30.3 \%$ (Fig. 2). 
The second group of less willingly consumed species constitute: lime $\left(14.8^{0} \%\right.$ of the utilized supply), hornbeam $\left(13.3^{\%} \%\right)$ and birch $\left(12.2^{\%} \%\right)$. The whitehorn $(7.2 \%)$ and elder $(5.9 \%)$ belong to species consumed reluctantly. The latter was, however, an attractive food for roe deer in the growing season.

The food preference appeared to be slightly different in old plantations showing a considerably higher supply of browse. The poplar was still the preferred species $\left(22.7^{\%} \%\right)$, but the supply of oak was utilized to a similar extent $(16.9 \%)$. This is related to the fact that deer browsed larger and heavier twigs from older oak trees (cf. Table 5). Further places in this food preference range are occupied by: willow $(12.0 \%$ utilization of browse supply), alder buckthorn $(10.0 \%)$, lime $\left(3.9^{\%} \%\right)$, hornbeam $(3.6 \%)$ birch $\left(2.4^{0} \%\right)$, whitehorn $(1.1 \%)$ and elder $(0.9 \%)$ (Fig. 2).

Hence the food preference of deer depends not only on the geographic region ( $\mathrm{Klein}, 1970$ ) but morover on the age of forest in the same area. The poplar, different species of willows and oaks, are known as attractive food for deer. In some cases these species may be completely eliminated by deer from the habitat ( $\mathrm{R}$ as m ussen, 1941; Grizez, 1959 - after De Vos \& Mosby, 1969). The studies on the food resources for roe and red deer carried out in Sweden (A h lé n, 1965) and Lithuania (Padaiga, 1968) confirmed that the twigs of poplar, alder buckthorn, willows and oaks constitute the preferred food of deer. A similar conclusion can be reached by the analysis of the stomach content of roe deer (Siuda, Żurowski \& Siuda, 1969), or by applying the test of preference for red deer ( $\mathrm{D}$ z i ęc i o łow sk i, 1970b). Only the data on the low preference of the elder and whitehorn are in disagreement with the results of some authors (Klötzli, 1965). This can be explained by seasonal changes in food habits of deer.

The damages caused in plantations by roe and red deer represent an important problem for the forest and hunting economy. In the studied area the oak is the most valuable tree species and its twigs are willingly browsed by deer. The introduction into plantations a higher number of such species as poplar, willow and alder buckthorn, which represent attractive food for roe and red deer, might considerably reduce the losses of valuable oak seedlings. Such a natural method based on the food preference of animals does not rule out the application of chemical or mechanical protection of seedlings from browsing ( $\mathrm{Szukiel}$, 1969: U e c k e rm a n, 1970).

Acknowledgements: The realization of these studies was possible due to the kindness of Mr. E. T a rko, M. Sc. Eng., Director of Forest Administration Centre - Kraków. Important suggestions and technical advice were obtained from direct menagers of these forests: Mr. T. Irzabek, M. Sc. Eng., Forest Inspector of Damienice, and Mr. T. Dajczer, Eng. from the Forest District Ispina. The authors are also grateful to Dr. W. Grodziński for critical evaluation of the manuscript. 


\section{REFERENCES}

1. A hlén I., 1965: Studies on the red deer, Cervus elaphus L., in Scandinavia. III. Ecological investigations. Viltrevy, 3, 3: 177-376.

2. De Vos A. \& Mos by H. S., 1969: Habitat analysis and evaluation. [In: "Wildlife management techniques«, Ed. R. H. Giles]: 135-172. The Wildlife Society, Washington D. C.

3. Dinesman L. G., 1967: Influence of vertebrates on primary production of terrestrial communities. [In: "Secondary productivity of terrestrial ecosystems «. Ed. K. Petrusewicz]: 261-266, Państw. Wyd. Nauk., Warszawa-Kraków.

4. Dzięciolowski R., 1969: Winter biomass of browse for herbivorous animals in forest habitats. Ekol. pol. A., 17, 20: 361-372.

5. Dzięciolowski R., 1970a: Foods of the red deer as determined by rumen content analyses. Acta theriol., 15, 6: 89-110.

6. Dzięciołowski R., 1970b: Food selectivity in red deer towards twigs of trees, shrubs and dwarf-shrubs. Acta theriol., 15, 23: 361-365.

7. Górecki A., 1965: The bomb calorimeter in ecological research. Ekol. pol. B., 11, 2: 145-158 [In Polish with English summ.].

8. Hadley E. B. \& Bliss L. C., 1964: Energy relationship of alpine plants on Mt. Washington, New Hampshire. Ecol. Monogr., 34: 331-357.

9. Halls L. K. \& Dell T. R., 1965: Tree-herbage relations in pine hardwood forest of Texas. J. Forestry, 63, 4: 282-283.

10. Halls L. K. \& Dell T. R., 1966: Trial of ranked-set sampling for forage yields. For. Sci., 12: 22-26.

11. Halls L. K. \& Epps E. A., 1969: Browse quality influenced by tree overstory in the South. J. Wildl. Mgmt., 33, 2: 1028-1031.

12. Klein D. R., 1970: Food selection by North American deer and their response to over utilization of preferred plant species. [In: "Animal populations in relations to their food resources«. Ed. A. W a tson]: British Ecological Soc. Symp., 10: 25-46. Blackwell Sci. Publ., Oxford and Edinburgh.

13. Klötzli F., 1965: Qualität der Rehäsung in Wald und Grünland-Gesellschaften des nördlichen Sweizer Mittellandes. Diss. Dokt. Naturwiss. Edidgenöss. Techn. Hochschule Zürich: 1-187. Zürich.

14. Kubota J., Riegers S. \& Lazar V. A., 1970: Mineral composition of herbage browsed by moose in Alaska. J. Wildl. Mgmt., 34, 3: 565-569.

15. Li e th H., 1968: The measurement of caloric values of biological material and the determination of ecological efficiency. [In: "Functioning of terrestrial ecosystems )of the primary production level - Proc. Copenhagen Symp., Ed. F. E. E c k a r d]: 179-186. UNESCO - Paris.

16. Pa daiga V. I., 1968: Permissible density of roes on Lithuania forest. [In Russian with English summ.]. Lesovedene, 2: 60-67.

17. P a da ig a V. I., 1970: Metody regulirovanija čislennosti olenej $\mathrm{v}$ intensivnom lesnom hozjajstve (Methods of deers number regulation in the intensive forest management): 1-32, Kaunas, Litovskij NIILH.

18. Pasławski T., 1969: Łowiectwo dla leśników i myśliwych. Państw. Wyd. Roln. i Leśne: 1-320, Warszawa.

19. Rasmussen D. J., 1941: Biotic communities of Kaibab Plateau, Arizona. Ecol. Monogr., 11: 229-275.

20. Schuster J. L., 1965: Estimating browse from twig and stem measurements. J. Range Mgmt., 18, 4: 220-222. 
21. Shafer J. L., Jr., 1963: The twig-count method for measuring hardwood deer browse. ¿. Wildl. Ngmt., 27: 428-437.

22. Siuda A., Żurowski W. \& Siuda, 1969: The food of the roe deer. Acta theriol., 14, 18: 247-262.

23. Szukiel E., 1969: Wyniki doświadczeń nad chemiczną ochroną upraw i młodników przed zwier yną. Syiwan, 113, 3: 49-55.

24. Telf er E. S., 1969a: Weight-diameter relationships for 22 woody plant species. Canadian J. Bot., 47, 12: 1851-1856.

25. Telf er E. S., 1969b: Twig weight diameter relationships for browse species. J. Wildl. Mgmt., 33, 3: 917-921.

26. Turček, F. J., 1969: Large mammals secondary production in European broad leaved and mixed forest. Biolcgia B., Zocl., 24, 2: 173-181.

27. U e ckermann E., 1969: Zeitaufwand, Materialverbrauch und Materialverlust für chemische Verbissschutzmittel bei Vergleich verschiedener Auftragsgeräte an einem Modell. Z. Jagdwiss., 15, 2: 72-81.

28. V a n é k J., 1958: Growth rate of available food for animals as underwood of oaker stands. [In Czech with English summ.]. Sbornik Československé Akademie Zemědělských Věd. Lesnictví. 31, 11: 971-994.

29. Yoakum J. \& Dasmann W., 1969: Habitat manipulation practices. [In: "Wildlife management techniques«, Ed. R. H. Giles]. The Wildl. Society, Washington D. C., $173-232$.

Accepted, March 16, 1972.

Department of Animal Genetics and Organic Evolution,

Jagiellonian University,

Kraków 2, Krupnicza 50, Poland.

Bogusław BOBEK, January WEINER i Jan ZIELIŃSKI

\section{BAZA POKARMOWA I JEJ WYKORZYSTANIE PRZEZ JELENIOWATE W GRĄDACH POLSKI POEUDNIOWEJ}

\section{Streszczenie}

Głównym pokarmem jeleniowatych jest tzw. żer pędowy, czyli bieżące przyrosty pędów drzew i krzewów, które znajdują się w zasięgu zwierzyny. Celem tej pracy była ocena zapasu i wykorzystania bazy pokarmowej sarn i jeleni na uprawach lasów grądowych Puszczy Niepołomickiej. Zapas żeru pędowego oceniono metodą żniwną, ścinając go latem, jesienią, zimą i wezesną wiosną na 42 ogrodzonych i nieogrodzonych działkach (każda o wymiarach $-5 \times 10 \mathrm{~m}$ ). Działki wytyczono w obrębie upraw leśnych $\mathrm{w}$ trzech stadiach wiekowych (3, 6 i 9 lat). Określano biomasę, suchą masę, wartość kaloryczną oraz ilość zgryzów przypadających zarówno na $1 \mathrm{~m}^{2}$ jak i na jedno-drzewko.

Zapas żeru pędowego (Tabela 1) najwyższy był latem i na uprawach starych, a najniższy zimą na uprawach młodych. Wartość kaloryczna żeru pędowego wahała się w granicach od 4,390 do $4,904 \mathrm{kcal} / \mathrm{g}$ suchej masy (Tabela 2). Po uwzględnieniu wartości energetycznych pokarmów dostępnych ich łączny zapas wyrażono w ka- 
loriach na $\mathrm{m}^{2}$ (Tabela 3). Przeciętnie $\mathrm{w}$ uprawach różnego wieku zapas pokarmu najwyższy jest $\mathrm{w}$ okresie lata $\left(567,0 \mathrm{kcal} / \mathrm{m}^{2}\right)$, a najniższy zimą $(125,9 \mathrm{kcal})$.

Skład jakościowy żeru pędowego na uprawach zmienia się w ciągu roku (Fig. 1). Latem dominuje w nim dąb $(70,1 \%)$, dalsze miejsca zajmują: jeżyna $(16,6 \%)$, grab $(9,1 \%)$, lipa $(2,3 \%)$, na inne gatunki przypada łącznie $2,1 \%$. Zimą znika z zapasu jeżyna, udział dębu wynosi $75,8 \%$, grabu $18,4 \%$, lipy $3,1 \%$, pozostałe gatunki stanowią łącznie $2,6 \%$.

Eksploatacja upraw przez jeleniowate jest bardzo intensywna w jesieni i szczególnie w zimie. Średnia liczba zgryzów wzrasta od $1,7 / \mathrm{m}^{2}$ w lecie, do $6,1 / \mathrm{m}^{2} \mathrm{w}$ jesieni i $15,7 / \mathrm{m}^{2} \mathrm{w}$ zimie (Tabela 4). Na podstawie pomiarów średnic zgryzów oceniono ich przeciętny ciężă. (Tabela 5). Zapas żeru pędowego dębu różnił się istotnie na działkach grodzonych i niegrodzonych we wszystkich klasach wieku upraw, jednak największe różnice stwierdzono $\mathrm{w}$ uprawach młodych $(27,4 \%)$. Istotne różnice wystapily także w zapasie liści jeżyn, natomiast nie wykryto ich w zapasie roślin runa.

$\mathrm{Z}$ różnicy $\mathrm{w}$ zapasie żeru na działkach niegrodzonych od zimy do wiosny oszacowano konsumpcję (Tabela 6). W tej samej tabeli podano również ocenę konsumpcji obliczoną z ilości i przeciętnego ciężaru zgryzów. Wyniki uzyskane obiema metodami różnią się o $28 \%$. W 7-miesięcznym okresie wegetacyjnym (kwiecień-październinik) konsumpcja pokarmu przez sarny i jelenie wynosiła 29,6 kcal na $\mathrm{m}^{2}$, z czego większość stanowią liście, a zaledwie 3,8 kcal przypadało na żer pędowy. $\mathrm{W}$ zimie (listopad-marzec) konsumpcja wynosiła $19,5 \mathrm{kcal} / \mathrm{m}^{2}$, zatem roczne pobranie pokarmu osiągało 49,1 kcal z każdego $\mathrm{m}^{2}$ uprawy. W stosunku do rocznej produkcji pokarmu dosteppnego, konsumpcja jeleniowatych stanowi więc $8.4 \%$, natomiast w okresie zimy zwierzęta te pobieraly $15,7 \%$ zapasu pokarmu. Najsilniej eksploatowane były uprawy młode, gdzie konsumpcja w okresie zimy osiągała aż $26,1 \%$ zapasu żeru pędowego. Liczebność zwierzyny płowej w badanym kompleksie lasów oceniono wstępnie na 12 sarn i 1,5 jelenia na 100 ha. Całkowita konsumpcja takiej populacji sięga w ciągu roku około $16,2 \mathrm{mln}$. kcal/ha. W stosunku do powierzchni, konsumpcja na uprawach była więc trzykrotnie wyższa niż w innych częściach lasu.

Najatrakcyjniejszym gatunkiem dla jeleniowatych okazała się topola osika $(81,0 \%$ wykorzystania zapasu uprawy młodej i $22,7 \%$ uprawy starej), dalsze miejsca zajmują: wierzba iwa (odpowiednio 44,1 i $12,0 \%)$, kruszyna $(36,3$ i $10,0 \%)$ i dąb $(30,3$ i $16,9 \%)$. W stosunku do innych drzew i krzewów jeleniowate wykazywaly niższą wybiórczość pokarmową (Fig. 2). Dąb jest gatunkiem zdecydowanie najcenniejszym z gospodarczego punktu widzenia. Skuteczną i stosunkowo tanią ochronę sadzonek dębu możnaby osiągnąć prawdopodobnie przez wprowadzanie do upraw większej ilości drzew i krzewów przeznaczonych dla zwierzyny. Nadawalyby się do tego takie atrakcyjne dla jeleniowatych a mało wartościowe gatunki jak osika, kruszyna, wierzba iwa. 